\begin{tabular}{|c|c|c|}
\hline Beitr. Ent. & Keltern & ISSN 0005-805X \\
\hline $\mathbf{5 7}(2007) 2$ & S. $347-354$ & 21.12 .2007 \\
\hline
\end{tabular}

\title{
Three new species of endogean Osoriini from southern Spain
}

\section{(Coleoptera: Staphylinidae: Osoriinae)}

With 10 figures and 1 map

\section{Volker Assing}

\begin{abstract}
Summary
Three endogean species of the osoriine genus Lusitanopsis CoIfFAIT, 1961 from southern Spain are described and illustrated: L. andujari sp. n. (Valencia: Sierra d'Aitana), L. segurica sp. n. (Castilla-La Mancha: Sierra de Segura), and L. meybohmi sp. n. (Andalucía: Sierra de Aracena). The distributions of these species are mapped. Additional records of Geomitopsis franzi CoIfFAIT, 1978 from the Canary Islands are reported, including a first record from La Palma.
\end{abstract}

Key words

Coleoptera, Staphylinidae, Osoriinae, Palaearctic region, Spain, taxonomy, new species, new records, endogean fauna

New species

Lusitanopsis andujari sp. n., L. segurica sp. n., L. meybohmi sp. n.

\section{Zusammenfassung}

Drei Arten der Gattung Lusitanopsis CoIffart, 1961 (Osoriinae) aus dem südlichen Spanien werden beschrieben und abgebildet: L. andujari sp. n. (Valencia: Sierra d'Aitana), L. segurica sp. n. (Castilla-La Mancha: Sierra de Segura) und L. meybohmi sp. n. (Andalucía: Sierra de Aracena). Die Verbreitung der Arten wird anhand einer Karte illustriert. Weitere Nachweise von Geomitopsis franzi CoIfFAIT, 1978 von den Kanarischen Inseln werden mitgeteilt, darunter ein Erstnachweis von La Palma.

\section{Introduction}

Lusitanopsis COIFFAIT 1961 previously included seven species, all of them distributed in the Iberian peninsula and the Canary Islands (Smetana 2004). According to Coiffait (1961), the genus is distinguished from its closest relatives, Cylindropsis Fauvel, 1885 and Bacillopsis Normand, 1920, by its aedeagus being "d'un type différent et en version à $90^{\circ}$ dans l'abdomen au repos", from the former additionally by the abdominal segment VII being approximately of similar length ("non ou à peine plus long") as the preceding segment (in Cylindropsis "nettement plus long"). The type species of Lusitanopsis is L. douroensis CoIffart, 1961 from the environs of Vila Réal, Portugal. 
Cylindropsis currently comprises nine species. Except for Cylindropsis littoralis CoIfFaIt, 1969 from southern Portugal (Algarve), all other species are distributed in Italy and France, most of them in Corsica and Sardinia; the type species of Cylindropsis, C. corsica (FAuvel, 1872), has been recorded from both Corsica and Sardinia.

In his seventh paper on endogean Osoriinae, Coiffart (1969) described one species of Cylindropsis, C. littoralis, and one of Lusitanopsis, L. monchicus, both from Algarve (southern Portugal). Remarkably, in the descriptions of both species it is stated that the abdominal segment VII is "une fois et demie plus long que les segments antérieurs", although in the key supplement given by Coiffait (1961) the relative length of the abdominal segment VII is the only character separating Lusitanopsis from Cylindropsis. Since 1969, at which time four species of Lusitanopsis were known, three additional species have been described.

The seventh species of Lusitanopsis, L. tenerifensis from Tenerife, Canary Islands, was described by Outerelo (1990), who compiled illustrations of the aedeagi of all known representatives of the genus, partly copied from Coiffait's papers. A comparison of the figures presented by Coiffait (e. g. 1961, 1969) and Outerelo (1990) shows that the aedeagi of Lusitanopsis are all of a similar type. The aedeagus of the type species of Cylindropsis is illustrated by CoIfFAIT (1955). There is little doubt that, if Lusitanopsis and Cylindropsis are really distinct genera (of which there is considerable doubt), Cylindropsis littoralis will have to be transferred to Lusitanopsis. First, the aedeagus is of the same type as that of other Lusitanopsis species. Second, the aedeagi of C. littoralis and L. tenerifensis are practically identical, and finally, closer affiliations of C. littoralis to Lusitanopsis species than to other representatives of Cylindropsis would also seem more plausible in view of the zoogeography of both genera (see above). Whether or not this species is conspecific with $L$. tenerifensis will have to be clarified based on an examination of types. It would not be surprising if $L$. tenerifensis turned out to be a recently introduced species. A colonisation of the Canary Islands by an endogean species would not seem very likely, and there are numerous examples of introductions of endogean insects with plant material and soil.

Apart from Lusitanopsis, only two other genera of endogean Osoriini are present in Spain, Bacillopsis (with one species from Mallorca) and Typhlosorius CoIffait, 1958 (originally described as a subgenus of Cylindropsis), with two species from Iviza and Castellón, respectively, and one from Alicante and Valencia; for illustrations of the aedeagus and other characters of the type species of Typhlosorius, T. torressalai (Coiffait, 1958), see Coiffait (1958). There are considerable doubts if the status of Typhlosorius as a distinct genus (or subgenus) is justified. According to CoIfFAIT (1958), the taxon is distinguished from Cylindropsis by the absence of lateral carinae on the pronotum and the elytra. However, a comparison of some species of Lusitanopsis from southern Spain revealed a high degree of interspecific variation regarding this character. In some species the elytral carinae are pronounced and stretching over the full length of the elytra, in others they are reduced to fine rudiments at the humeral angles, suggesting that the complete reduction is an expression of intrageneric rather than intergeneric variation.

The present paper is mainly based on material collected by Carmelo Andújar, who has recently begun to investigate the endogean beetle fauna, primarily Anillini (Carabidae), of Murcia and adjacent areas by soil-washing. In the course of his studies, he not only discovered two of the Osoriini described below, but also undescribed species of Leptotyphlinae and Aleocharinae (Assing, in press). 


\section{Material and methods}

The material referred to in this study is deposited in the following collections:

cAnd private collection Carmelo Andújar, Murcia

cAss author's private collection

cGar private collection Rafael García Becerra, Santa Cruz de La Palma

The morphological studies were carried out using a Stemi SV 11 microscope (Zeiss Germany) and a Jenalab compound microscope (Carl Zeiss Jena) with a drawing tube. For the photographs a digital camera (Nikon Coolpix 995) was used.

Elytral length was measured at the suture from the apex of the scutellum to the posterior margin of the elytra.

The map was generated using the online generic mapping tool (GMT) of the Geomar website at www. aquarius.ifm-geomar.de/omc.

\section{Species descriptions and additional records}

Lusitanopsis andujari sp. n. (Figs 1-4, Map 1)

\section{Type material:}

Holotype ơ: E - Alicante [11], Sierra d'Aitana, ca. 8 km N Sella, 1390 m, 38³9'09N, 00¹6'02W, 28.III.2007, C. Andújar / Holotypus ơ Lusitanopsis andujari sp. n. det. V. Assing 2007 (cAss). Paratypes: $30^{\star} o^{\star}, 6+9$ : same data as holotype (cAnd, cAss).

\section{Description:}

2.3-2.6 mm. Coloration uniformly reddish.

Head with extremely fine puncturation; microreticulation rather distinct in anterior and lateral areas, and very shallow to almost obsolete in median dorsal area (Fig. 1). Eyes completely reduced. Antenna (Fig. 2) with antennomere I short, slender, and moderately flattened; II small, narrower than I; III approximately as long as wide, IV distinctly transverse; IV-VI increasingly transverse and of gradually increasing width; VII distinctly larger than VI; VII-XI forming a moderately distinct club.

Pronotum approximately 1.05 times as wide as head and 1.1 times as wide as long, widest near anterior angles; lateral margins converging in straight or weakly convex line posteriad in dorsal view, anterior margin 1.35-1.40 times as wide as posterior margin (Fig. 1); lateral margins without carinae; disc with two median rows of 6-8 punctures; area between these rows impunctate, with or without shallow traces of microsculpture; lateral areas with distinct microreticulation.

Elytra as wide as or slightly narrower than pronotum, at suture 0.63-0.70 times as long as pronotum; shape (of both elytra combined) transversely rectangular; anterior 1/4 of lateral margins distinctly carinate, this carina distinctly dilated at humeral angles and clearly visible from above, humeral angles well-marked (Fig. 1); surface with shallow, but distinct microreticulation and with extremely fine (barely noticeable) sparse puncturation. Hind wings completely reduced.

Abdomen 1.05-1.10 times as wide as elytra, widest at segment VII; microsculpture of segments III-VII more pronounced than that of forebody, composed of relatively large and more or less isodiametric meshes.

$0^{\star}$ : aedeagus as in Figs 3-4. 


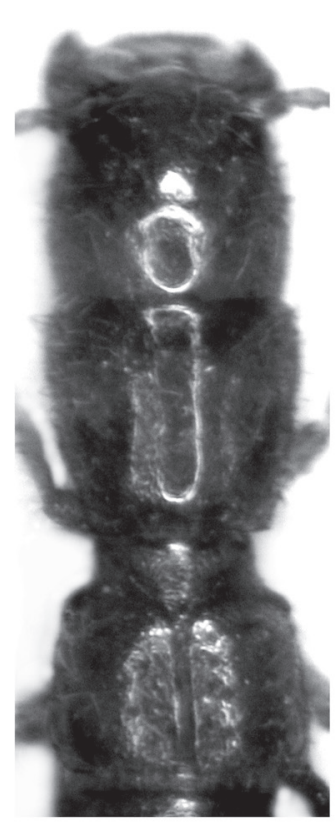

1

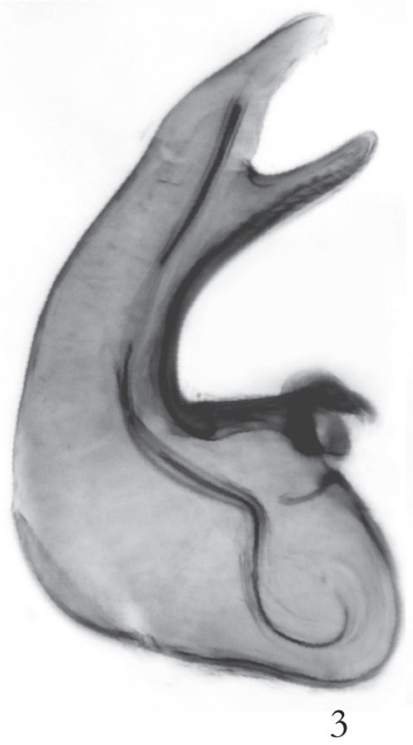

3

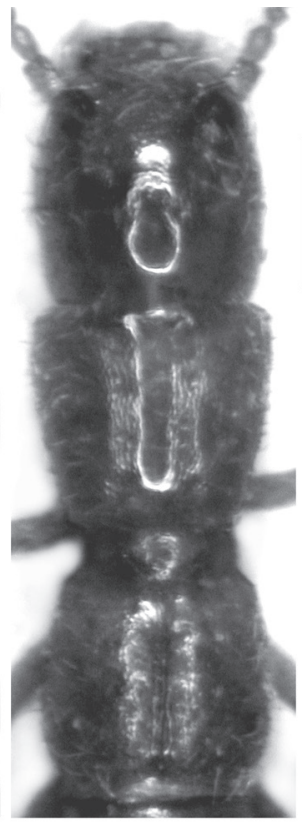

5

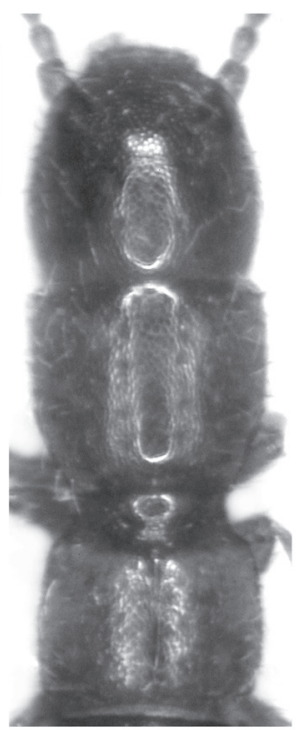

8

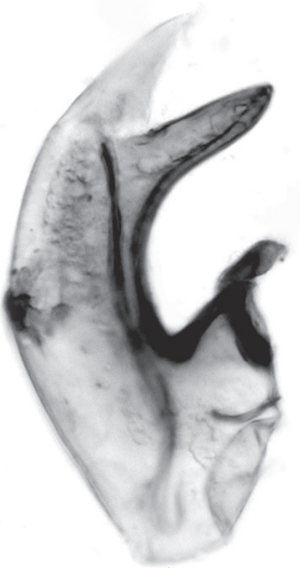

10
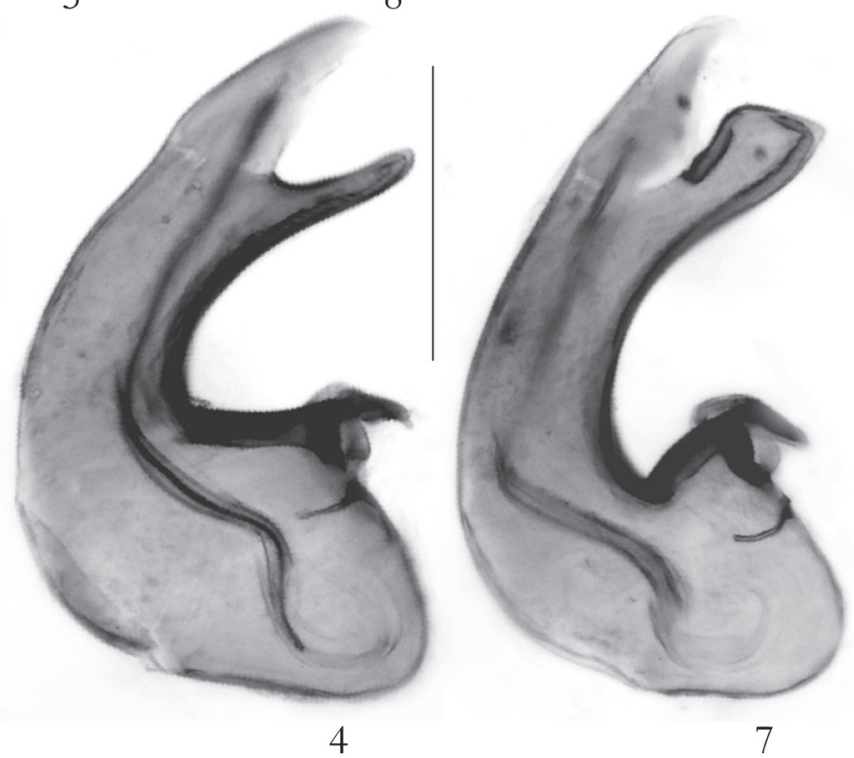

7

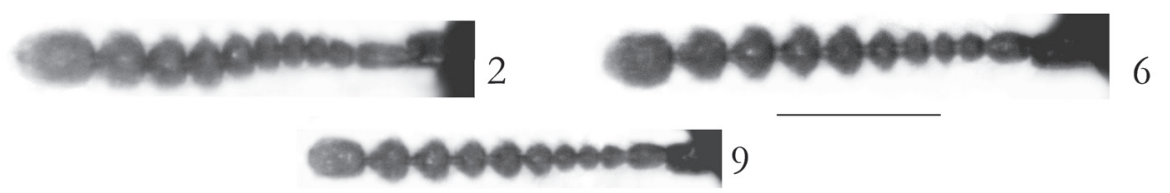

Figs 1-10: Lusitanopsis andujari sp. n. (1-4), L. segurica sp. n. (5-7), and L. meybohmi sp. n. (8-10): forebody $(1,5,8)$; antenna $(2,6,9)$; aedeagus in lateral view $(3-4,7,10)$. Scale bars: 1-2, 5-6, 8-9: 0.2 mm; 3-4, 7, 10: $0.1 \mathrm{~mm}$. 


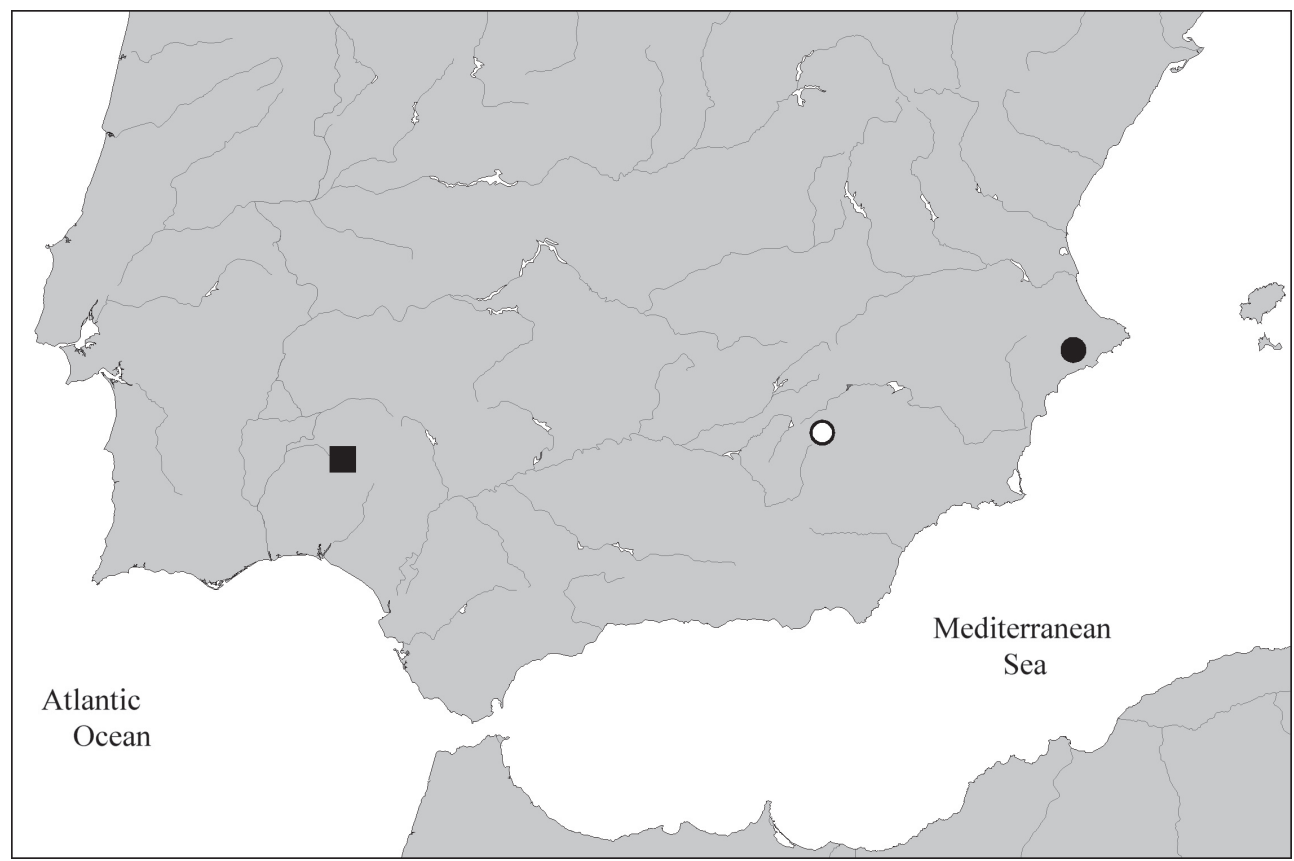

Map 1: Distributions of Lusitanopsis andujari sp. n. (filled circle), L. segurica sp. n. (open circle), and L. meybohmi sp. n. (square) in southern Spain.

Etymology: The species is dedicated to my friend Carmelo Andújar, a most enthusiastic collector of endogean beetles, to whom I am grateful for the generous gift of most of the type specimens.

\section{Comparative notes:}

The new species is separated from all its congeners especially by the distinctive shape of the aedeagus (lateral view). From Typhlosorius torressalai, the only other species of Osoriini known from Alicante, it is distinguished by the presence of pronounced lateral carinae in the anterior half of the elytra and by the different shape of the aedeagus. For illustrations of Typhlosorius torressalai see Coiffart (1958). For illustrations of the aedeagi of other endogean Osoriini from the Iberian peninsula see Coiffait $(1958,1961,1965,1969)$ and Outerelo (1990).

\section{Distribution and bionomics:}

The type locality is not far from the peak of the Sierra d'Aitana near Alicante (Map 1), at an altitude of almost $1400 \mathrm{~m}$. The types were collected by washing soil from a rocky pasture and from a north slope in the shade of big rocks.

\section{Lusitanopsis segurica sp. n. (Figs 5-7, Map 1)}

\section{Type material:}

Holotype ơ: E - Castilla-La Mancha, Sierra de Segura, $20 \mathrm{~km}$ WSW Nerpio, $1490 \mathrm{~m}, 38^{\circ} 04^{\prime} 02 \mathrm{~N}$, 02³0'14W, 17.XII.2005, C. Andújar / Holotypus ơ Lusitanopsis segurica sp. n. det. V. Assing 2007 (cAss). Paratype ơ: same data as holotype (cAss). 


\section{Description:}

2.5-2.6 mm. Coloration uniformly reddish.

Head as in L. andujari (Fig. 5), but with antenna of different morphology (Fig. 6): antennomere I larger, distinctly flattened, and of subrectangular shape; II large, almost as wide as I; antennomere III wider than long.

Pronotum of similar shape and relative size as in L. andujari; dorsal rows composed of 5-6 punctures; area between these rows almost completely without microreticulation (Fig. 5).

Elytra narrow, 0.90-0.95 times as wide and at suture 0.75-0.80 times as long as pronotum; shape (of both elytra combined) not distinctly transversely rectangular, lateral margins weakly convex in dorsal view; at humeral angles only with narrow rudiment of carina; humeral angles weakly marked (Fig. 5); surface with distinct microreticulation and with sparse, relatively coarse punctures. Hind wings completely reduced.

Abdomen 1.15-1.20 times as wide as elytra, widest at segment VII; microsculpture of segments III-VII similar to that of $L$. andujari.

$\sigma^{\top}$ : aedeagus as in Fig. 7.

Etymology: The name (adj.) is derived from the mountain range where the type locality is situated.

\section{Comparative notes:}

The new species is characterised especially by the shape of the aedeagus. From the preceding species, it is additionally separated by the morphology of the antennae, the differently shaped elytra (distinctly more slender and not of transversely rectangular shape), and the much less pronounced carinae at the weakly marked humeral angles (see description). For references to figures of the aedeagi of other endogean Osoriini occurring in the Iberian Peninsula see the comparative notes in the section on L. andujari.

\section{Distribution and bionomics:}

The type locality is situated in the eastern parts of the Sierra de Segura (Map 1). The specimens were collected by soilwashing in a mixed forest with walnut and other deciduous trees near a stream at an altitude of almost $1500 \mathrm{~m}$.

\section{Lusitanopsis meybohmi sp. n. (Figs 8-10, Map 1)}

\section{Type material:}

Holotype $\sigma^{\top}: \mathrm{N}^{\circ} 7^{\circ} 53^{\prime}, \mathrm{W}_{006}^{\circ} 46^{\prime}$, E Andalusien, Sierra de Aracena, 910 m, Meybohm, 5.4.2001 / Holotypus ơ Lusitanopsis meybohmi sp. n. det. V. Assing 2007 (cAss).

\section{Description:}

$2.1 \mathrm{~mm}$. Coloration reddish brown, legs and antennae dark yellowish.

Head as in L. andujari, but with pronounced microreticulation everywhere (Fig. 8) and antenna of different morphology (Fig. 9): antennomere I larger, distinctly flattened, and of subrectangular shape; II distinctly narrower than I; size of VI intermediate between that of V and VII, i. e. antennal club less distinctly separated from base of antenna.

Pronotum approximately as wide as head and 1.15 times as wide as long; anterior 2/3 of lateral margins subparallel and posterior 1/3 distinctly converging (Fig. 8); dorsal rows composed of 
approximately 5 punctures; area between dorsal rows with pronounced microreticulation (similar to that of lateral parts).

Elytra of similar shape as in L. andujari, 0.93 times as wide and 0.65 times as long as pronotum, and of transversely rectangular shape (Fig. 8); whole length of lateral margins finely carinate (visible also when viewed from above); surface with shallow, but distinct microsculpture and rather fine puncturation. Hind wings completely reduced.

Abdomen 1.13 times as wide as elytra, widest at segment VII; microsculpture of segments III-VII similar to that of L. andujari.

$\mathrm{o}^{\mathrm{t}}$ : aedeagus as in Fig. 10.

Etymology: The species is dedicated to Heinrich Meybohm, Großhansdorf, who collected the holotype while looking for Scydmaenidae.

\section{Comparative notes:}

Lusitanopsis meybohmi is distinguished from its congeners especially by the shape of the aedeagus. From the two preceding species, it is additionally separated by the pronounced microsculpture in the central dorsal area of the head and in the area between the dorsal rows of punctures on the pronotum, the antennal morphology (see description above), the shape of the pronotum (lateral margins abruptly converging in posterior $1 / 3$ in dorsal view), and the long fine carina at the lateral margins of the elytra. From L. segurica, it is also distinguished by the broader and transversely rectangular elytra.

\section{Distribution and bionomics:}

The holotype was discovered near the Mirador San Cristobal in the Sierra de Aracena (Huelva, near Cortegana in western Andalucía) by sifting soil in the shade of big rocks at an altitude of $910 \mathrm{~m}$ (Меувонм pers. comm.).

\section{Geomitopsis franzi CoIfFaIT, 1978}

\section{Material examined:}

Canary Islands: Tenerife: 1 ex., Anaga, Chinobre, 850 m, 13.IV.1992, leg. Assing (cAss); 1 ex., Anaga, 6 km E El Bailadero, near Chinobre, 900 m, sifted, 10.II.1999, leg. Lehmann (cAss); 1 ex., Vueltas Taganana, 5.III.1985, leg. Oromí (cAss); 1 ex., Zapato, 20.II.1990, leg. Oromí (cAss). La Palma: 4 exs., Bco. Pineros, 10.VI.2005, leg. García (cGar, cAss).

\section{Comment:}

This Canarian endemic was previously known only from Gran Canaria and Tenerife (Machado \& Oromí 2000). It is here reported from La Palma for the first time.

\section{Acknowledgements}

I am indebted to Carmelo Andújar and Heinrich Meybohm for the generous gift of the material which this paper is based on. Benedikt Feldmann (Münster) proof-read the manuscript. 


\section{References}

Assing, V. in press: Four new species and additional records of Staphylinidae from Spain (Coleoptera: Staphylinidae). - Linzer biologische Beiträge 39 (2) (2007).

Coiffait, H. 1955: Contribution a la connaissance des Osoriini anophtalmes [sic] (Coleoptera, Staphylinidae). - Revue Françaises d'Entomologie 22: 262-269.

Coiffart, H. 1958: Nouveaux Osoriini anophtalmes de la côte méditerranéenne espagnole (Coleoptera, Staphylinidae). - Notes Biospéologiques 12 (1957): 111-116.

Coiffart, H. 1961: $4^{\circ}$ note sur les Osoriini anophtalmes méditerranéens. Description d'un nouveau genre portugais (Coleoptera, Staphylinidae). - Revue Françaises d'Entomologie 28: 79-82.

Coiffait, H. 1965: Nouveaux Osoriini endogés de la région méditerranéenne occidentale (Coleoptera, Staphylinidae). $5^{\circ}$ note. - Revue d'Écologie et de Biologie du Sol 2: 285-290.

Coiffait, H. 1969: Nouveaux Osoriini hypogés. - Annales de Spéléologie 24: 163-170.

Machado, A. \& Oromí, P. 2000: Elenco de los coleópteros de las Islas Canarias. - Instituto de Estudios Canarios, La Laguna: 306 pp.

Outerelo, R. 1990: El género Lusitanopsis (Coleoptera, Staphylinidae), nuevo en las Islas Canarias, con una nueva especie, $L$. tenerifensis. - Nova Acta Científica Compostelana (Bioloxía) 1: 25-29.

\section{Author's address:}

Dr. VolKer Assing

Gabelsbergerstr. 2

30163 Hannover, Germany

e-mail: vassing.hann@t-online.de

\section{Subject editor:}

Dr. L. Zerche

\section{Besprechungen}

Wermelinger, B.; Forster, B. \& Godet, J.-D.: Borkenkäfer. Alle forstlich wichtigen Rinden- und Holzbrüter. - Stuttgart: Verlag Eugen Ulmer KG, 2007. - 64 S. (GODET Naturführer). - ISBN 978-38001-5571-2.

Borkenkäfer sind wegen ihrer medialen Präsenz bei Massenvermehrungen einer breiten Öffentlichkeit bekannt, im Gegensatz zu vielen anderen Käfern. Im vorliegenden Buch werden 15 Arten vorgestellt, die als Schaderreger besondere Bedeutung haben. Für jede Art gibt es informative Fotos: Habitus, Detailaufnahmen wichtiger Erkennungsmerkmale und - bei Borkenkäfern besonders wichtig - Fraßbilder. Der knapp gehaltene Text bietet dazu wesentliche Informationen. Er ist gegliedert in Käfer (Erkennungsmerkmale), Brutbild, Haupt-Flugzeiten, Generationen, Überwinterung, Wirtsbäume und Verbreitung. Einleitende Kapitel beschäftigen sich mit der Biologie, der Bedeutung (wirtschaftliche und ökologische, Ursache des Ulmensterbens), den Maßnahmen gegen Borkenkäferbefall und den natürlichen Feinden. Nach den Käfern werden in ähnlicher Weise acht Wirtsbaumarten vorgestellt, auch hier sehr gut illustriert. Wer in die Borkenkäferkunde einsteigen möchte, kann dies mit dem vorliegenden Buch ohne Vorkenntnisse tun. Geschrieben für den Praktiker, den die anderen Borkenkäferarten nicht interessieren, enthält das Buch auf engem Raum eine Fülle an Informationen.

L. ZERCHE 